\title{
Synthesis, characterization and antimicrobial activity of nano-crystalline tricalcium silicate bio-cement
}

\author{
H. K. Abd El-Hamid*, H. H. Abo-Almaged, M. M. Radwan \\ Refractories, Ceramics and Building Materials Department, National Research Centre (NRC), Dokki, 12622 Cairo, Egypt.
}

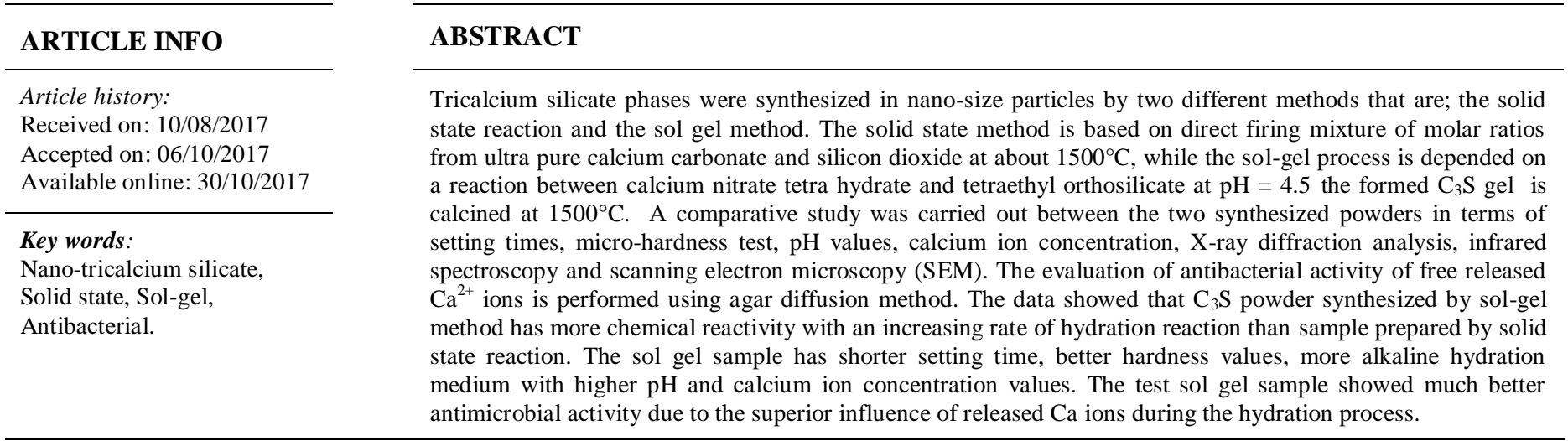

\section{INTRODUCTION}

Tricalcium silicate $\left(\mathrm{C}_{3} \mathrm{~S}\right)$ is the main component of mineral trioxide aggregate (MTA). It constitutes approximately $52 \%$ of the un-hydrated material (Formosa et al., 2012; BelioReyes et al., 2009). Both MTA and tricalcium silicate cements have confirmed bioactivity as a new phase of dental materials, namely the hydraulic silicate cements (Darvell and Wu, 2011), i.e. both form a bone-like hydroxyapatite layer on the surface when immersed in physiological solution (Sarkar et al., 2005; Reyes-Carmona et al., 2009; Coleman et al., 2007; Gandolfi et al., 2010). It is also contributory in maintaining the interface of bone-biomaterial if implanted in the body (Zhao et al., 2005). It was proved that silicon ion derived from calcium silicate-based biomaterials has an important role in stimulating proliferation,

\footnotetext{
* Corresponding Author

Hanaa Kame lAbd El-Hamid, Refractories, Ceramics and Building Materials Department, National Research Centre (NRC), Dokki, 12622

Cairo, Egypt. E-mail:hanaa772004 @ yahoo.com,Tel: +201224006118
}

differentiation, osteogenic gene expression of osteo-related cells (Wenjuan et al., 2015). Furthermore, $\mathrm{C}_{3} \mathrm{~S}$ phases have advantageously a relatively low setting time compared with MTA, which is very suitable for replacement of MTA dental material as it has the same chemical composition and bioactivity (Chen et al., 2009). It also possesses excellent injectability, high bioactivity and moderate in vitro degradability and ultimately the body will be able to replace the implanted cement by natural tissue (Zhao et al., 2005). Hydration of Tricalcium silicate results in producing calcium silicate hydrate gel and free lime (calcium hydroxide, $\mathrm{Ca}(\mathrm{OH})_{2}$ ) leaving a small portion of un-reacted material (Formosa et al., 2012; Zhao et al., 2005; Camilleri, 2011). The hydration of tricalcium silicate $\left(\mathrm{C}_{3} \mathrm{~S}\right)$ is shown in Eq. (1) (Taylor, 1997).

$$
3 \mathrm{CaO} \mathrm{SiO}_{2}+\sim 5.3 \mathrm{H}_{2} \mathrm{O} \rightarrow \sim 1.7 \mathrm{CaO} . \mathrm{SiO}_{2} \cdot 4 \mathrm{H}_{2} \mathrm{O}+\sim 1.3 \mathrm{Ca}(\mathrm{OH})_{2}(1)
$$

The $\mathrm{Ca}(\mathrm{OH})_{2}$ released from the tricalcium silicate hydration possesses antibacterial and anti-inflammatory properties (Wang et al., 2008) because of the high (alkalinity) $\mathrm{pH}$ of the surrounding medium after it dissolves (Siqueira and Lopes, 1999). 
Also, the released $\mathrm{Ca}(\mathrm{OH})_{2}$ may induce mineralization resulting in a repair of damaged dentin matrix (Estrela et al., 1995). Pure tricalcium silicate can be prepared by solid state reaction or by the sol-gel method (Zhao and Chang, 2004).

In this work, a comparison study of tricalcium silicate phases prepared in the laboratory by two different methods; solid state reaction at elevated temperature and sol-gel method, was carried out by determining some physico-mechanical and hydration behavior such as setting times, hardness test, $\mathrm{pH}$ of curing medium, calcium ion determination, X-ray diffraction analysis, infrared spectroscopy and scanning electron microscopy. The evaluation antibacterial activity of both materials as influenced by the method of preparation.

\section{MATERIALS AND METHODS}

\section{Materials preparation and characterization}

Tricalcium silicate bio-ceramic has been prepared by two different methods as follows:

\section{a. Solid state reaction}

$\mathrm{C}_{3} \mathrm{~S}$ phase (S1) was synthesized by firing molded cubes of 3:1 $\mathrm{CaO}: \mathrm{SiO}_{2}$ molar ratio, using ultra pure $\mathrm{CaCO}_{3}$ and quartz $\left(99.6 \% \mathrm{SiO}_{2}\right)$, in the presence of $0.5 \%$ boric acid at $1000^{\circ} \mathrm{C}$ for 2- hours (Lea, 2004). The product was ground, remolded using carbon tetrachloride and fired at $1450^{\circ} \mathrm{C}$ for 2-hours. The firing process was repeated until completion of the reaction. The end product was checked for the presence of free lime.

\section{b. Sol-gel method}

Tricalcium silicate powder $\left(\mathrm{C}_{3} \mathrm{~S}-\mathrm{S} 2\right)$ was synthesized by sol-gel method as described by H. Zhen et al. (Zhen et al., 2010). Formulation of $\mathrm{C}_{3} \mathrm{~S}$ phase by this method is based on the reaction between calcium nitrate tetra hydrate $\mathrm{Ca}\left(\mathrm{NO}_{3}\right)_{2} \cdot 4 \mathrm{H}_{2} \mathrm{O}$ and tetraethyl orthosilicate (TEOS), $\left(\mathrm{Si}\left(\mathrm{OC}_{2} \mathrm{H}_{5}\right)_{4}\right) .1 .5 \mathrm{~mol}$ of $\mathrm{Ca}\left(\mathrm{NO}_{3}\right)_{2} \cdot 4 \mathrm{H}_{2} \mathrm{O}$ was added drop wise to a solution of $0.5 \mathrm{~mol}$ TEOS in $200 \mathrm{ml}$ water during continuous stirring. The $\mathrm{pH}$ of the solution should be adjusted at 4.5 with the aid of nitric acid. The mixture was heated to $50-55{ }^{\circ} \mathrm{C}$ for $2 \mathrm{~h}$ and the solution temperature was maintained at $75{ }^{\circ} \mathrm{C}$ for $24 \mathrm{~h}$. The prepared gel has been dried at $120{ }^{\circ} \mathrm{C}$ over night and calcined at $1500{ }^{\circ} \mathrm{C}$ at a firing rate of $10^{\circ} \mathrm{C} / \mathrm{min}$ for $9 \mathrm{~h}$.

The two synthesized powders were investigated by X-ray diffraction (XRD) to verify the identity of the synthesized compound, using a copper target with radiation; wavelength $=1.54$ $\mathrm{nm}, \mathrm{X}$-ray was generated at $40-\mathrm{KV}$ with a current of 2-5-Ma. The scanning speed was $1 \%$ minute (Fig. 1(a,b)). The final materials were finely ground in an agate mill until the desired particle size, which was evaluated by Transmission Electron Microscope (TEM) (JEM-1230) at 100Kv (Fig. 2 (a, b)).
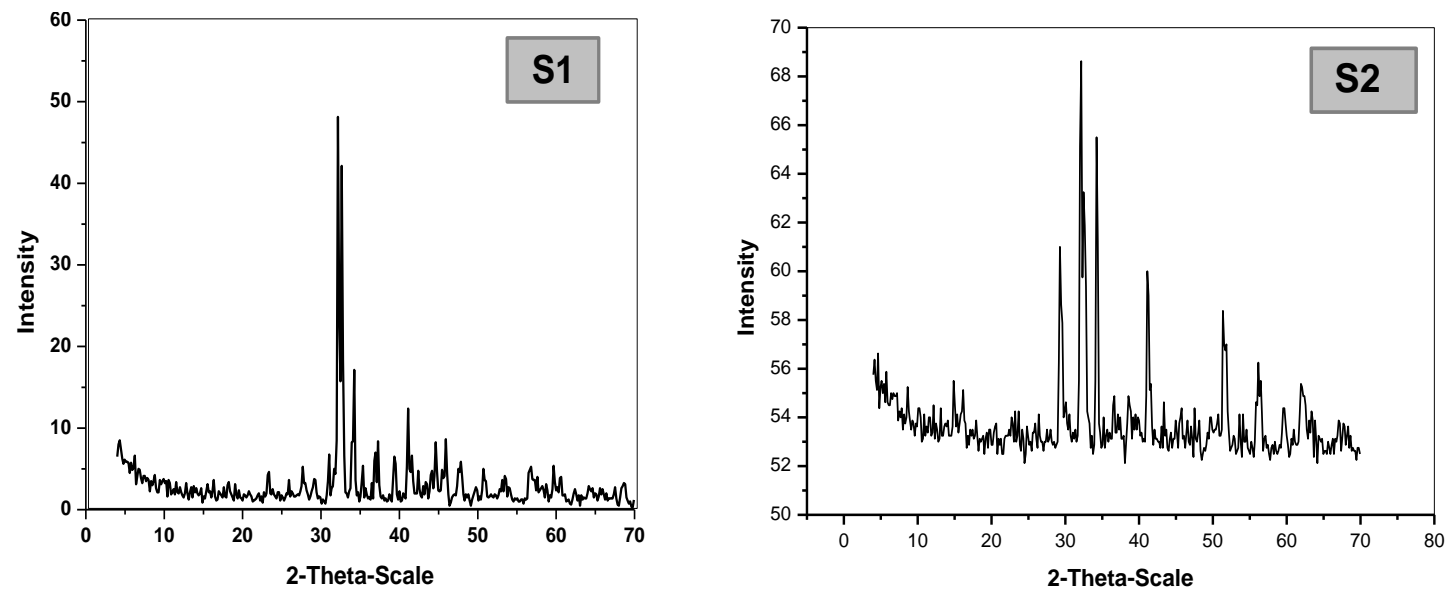

Fig. 1: XRD patterns of tricalcium silicate synthesized by two different methods.

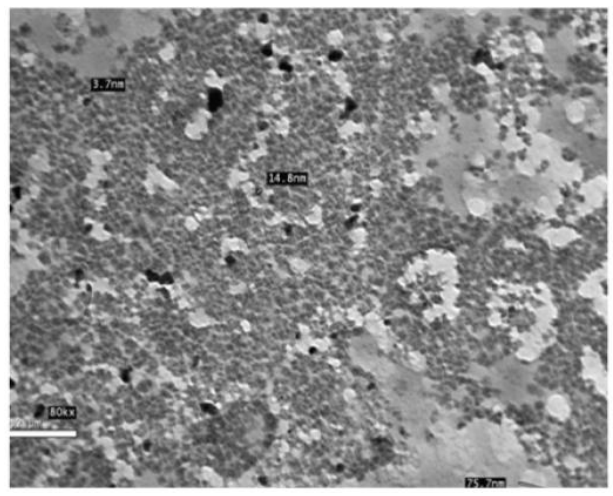

A

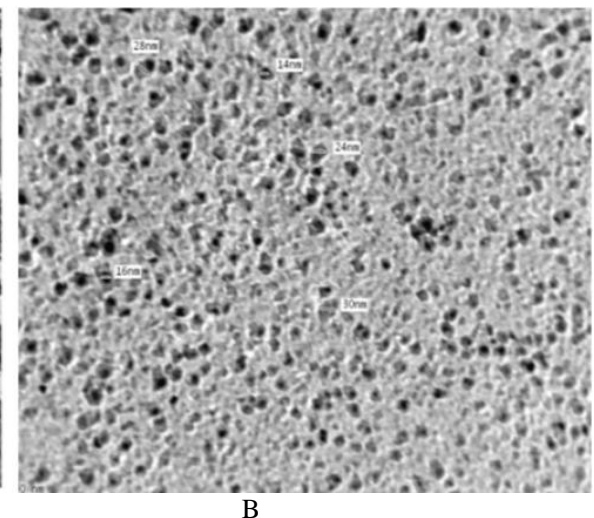

B

Fig. 2: Transmission electron photomicrograph of both tricalcium silicate synthesized by two different methods, (a) S1 particle size ranged from 3-75 $\mathrm{nm}$ and (b) S2 particle size ranged from 14-30 nm. 


\section{Physical characteristics of the two synthesized materials Setting time}

The setting time for this work was carried out according to ANSI/ADA specification no. 57 for root canal sealers and cements. Five Scoops of the powder were mixed with the required drops of distilled water that give the best workable paste to fill a mold of dimensions; $10 \mathrm{~mm} \pm 0.1 \mathrm{~mm}$ height. Mixing was done on a clean glass slab with a clean spatula, for thirty seconds. Each mold was placed on a glass plate $1-\mathrm{mm}$ thick $X 25 \mathrm{~mm}$ wide $\mathrm{X} 75$ $\mathrm{mm}$ long and filled with the tested $\mathrm{S} 1$ and $\mathrm{S} 2$ pastes to a level surface.

After $120 \pm 5$ seconds from the beginning of mixing, the assembly was placed in a cabinet maintained at $37 \pm 1{ }^{\circ} \mathrm{C}$ temperature and $95 \%$ relative humidity. The Gilmore needle (having a flat end diameter of $2 \mathrm{~mm} \pm 01 \mathrm{~mm}$ ) was carefully lowered on to the horizontal surface of the material. Indentations were repeated at 30 -second intervals until the indenter fails to make a complete circular indentation in the cement. The indenter was wiped clean between indentations.

\section{Hardness test}

The prepared pastes of both synthesized materials were poured into a cylindrical brass mold (diameter $=10 \mathrm{~mm}$, height $=$ $2 \mathrm{~mm}$ ). The paste was placed in the mold into two approximately equal layers. Each layer was compacted and pressed along the surface of the mold until homogenous specimen was obtained. Immediately after molding, the samples were cured in a humidity chamber at $100 \%$ relative humidity at a constant temperature of 37 ${ }^{\circ} \mathrm{C}$ for $24 \mathrm{~h}$. At the end of the moist curing period the samples were demoulded and then cured under distillated water until the time of testing at a constant temperature of $37{ }^{\circ} \mathrm{C}$ such as 1,3 , 7 and 28 days.

The hardness test (Eid et al., 2012) was carried out on three samples of each case of the hardened cement pastes. The test was performed with a Vickers indentation hardness tester at five points on one side of each sample. A load of $1 \mathrm{Kg}$ was applied for 15 seconds and the depth of indentation was then recorded.

\section{pH of immersion solution and calcium ion concentration}

To test in vitro $\mathrm{pH}$ variation and calcium ion released of the two types cement pastes $(\mathrm{S} 1 \& \mathrm{~S} 2)$ in distilled water. 1/2 inch cylinder of each type of cements was directly poured into a $25 \mathrm{ml}$ beaker and then $15 \mathrm{ml}$ of distilled water was injected into the container to cover the paste (Nurit et al., 1993). The test samples were stored in a $37^{\circ} \mathrm{C}, 100 \%$ humidity water bath. After 3,7 and 28 days of immersion all solutions were filtrated and the $\mathrm{pH}$ value was measured using an electrolyte-type $\mathrm{pH}$ meter and the concentration of calcium ion was measured by atomic absorption spectra (Savant AA, GBC, Australia)..

\section{X-ray diffraction of the prepared cement pastes}

Selected hydrated samples were investigated by X-ray diffraction (XRD) to verify the identity of the hydrated compounds.

\section{ATR/FTIR Spectroscopy}

The hydrated specimens of the two synthesized materials were investigated using IR spectra. IR spectra were recorded on JASCO 4600 model FTIR spectrometer.

\section{Scanning electron microscopy (SEM)}

The morphology of the hydrated dry samples of the two specimens was investigated using scanning electron microscopy (SEM), with the aid of (Jeol JSM-T 20 ) after coating of the samples by a thin layer of gold using sputter coater $\mathrm{S}_{150} \mathrm{~A}$.

\section{Antibacterial Activity}

The antimicrobial activity of both synthesized materials (S1\&S2) has been done at one concentration by the agar diffusion method against reference strain of staphaurogenosa. Bacteria were diluted to obtain a suspension of approximately $5 \times 10^{8}$ colonyforming units/ml (0.5in a McFarland ephelometer) in sterile TSB (Trypticase Soy Broth) (Merck, Germany) (McFarland, 1907). Microbial strain was confirmed by both Gram staining and colony forming and growth characteristics. Staphauggenosa was inoculated with sterile cotton swabs onto TSA agar (Merck). Wells $4 \mathrm{~mm}$ in diameter and $4 \mathrm{~mm}$ deep were prepared on plates with a copper puncher, and immediately filled with freshly manipulated test materials. Positive controls antibiotic Gentamycin incubated for the same period under identical conditions. After prediffusion of the test materials for $2 \mathrm{~h}$ at room temperature, all the plates were incubated at $37^{\circ} \mathrm{C}$ and evaluated at 24,48 and $72 \mathrm{~h}$. Microbial inhibition zones were measured with a $0.5-\mathrm{mm}$ precision ruler.

\section{RESULTS}

\section{Setting time}

Fig. (3) shows the setting times of the two synthesized tricalcium silicate samples ( $\mathrm{S} 1$ and $\mathrm{S} 2$ ). The data reveal that the setting time of the $\mathrm{C}_{3} \mathrm{~S}$ sample prepared by the sol-gel method (S2) is lower than that of $\mathrm{S} 1$ sample by about 4-5 min, but both samples showed their setting times within a time range of 30-35 min that is very important for dental and medical applications as it is suitable time range to manipulate such material that has good mechanical properties comparing with calcium phosphate cements (Radwan et al., 2016).

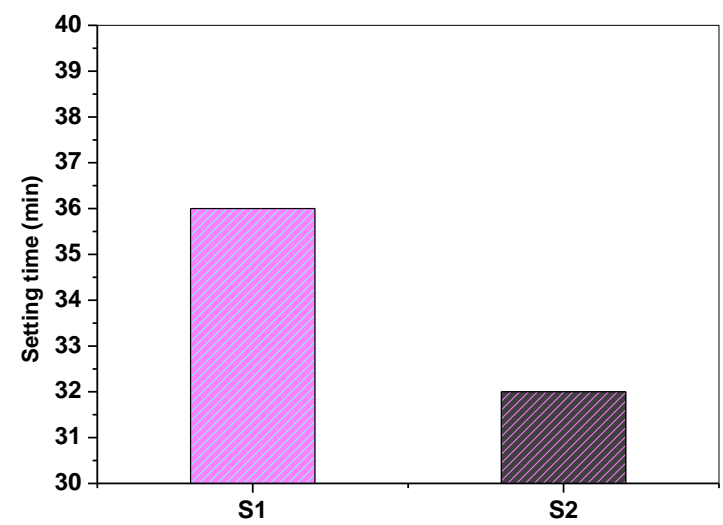

Fig. 3: Setting time of the two synthesized materials (S1 and S2). 


\section{Micro hardness}

The hardness test for the two investigated materials (S1\&S2) was considered in this study as a guide for the mechanical properties of the prepared $\mathrm{C}_{3} \mathrm{~S}$ phase. Fig.4. shows the hardness Vickers values in relation with the curing periods of the two materials (S1\&S2). The data indicate that for both samples the hardness Vickers values showed a steady increase with curing period up to 7 days and from 7 to 28 days a little increase or almost same hardness values were detected. The tricalcium silicate phase S2 that is synthesized by sol-gel method showed higher hardness values at all curing periods.

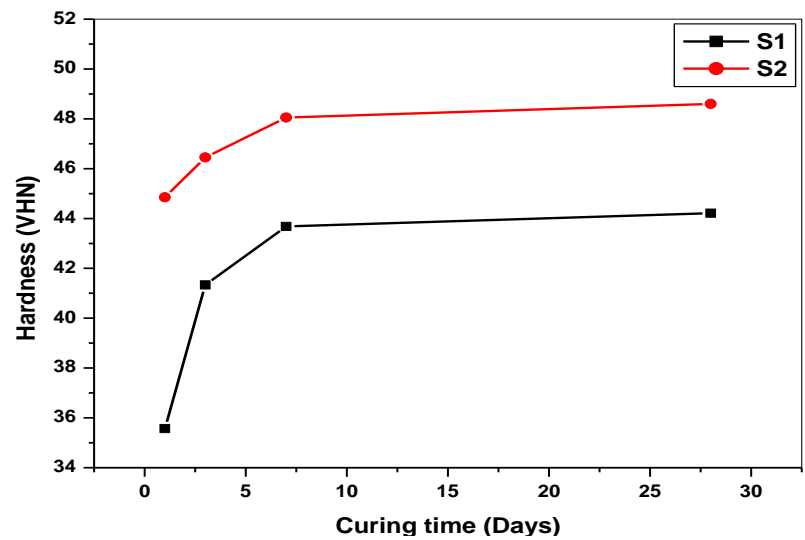

Fig. 4: Micro hardness of the two synthesized materials (S1 and S2).

\section{pH variations of the curing medium}

The $\mathrm{pH}$ values given in Fig. 5 reveal that the curing medium of S2 sample is more alkaline than that of S1 as it showed higher $\mathrm{pH}$ values at all curing ages. These values were found to be almost constant in the range between $\mathrm{pH}$ 11-11.2 up to 28 days curing periods. For sample prepared by solid state reaction (S1), the $\mathrm{pH}$ values slightly decrease from 3 to 7 curing age, followed by a strong decrease for the 28 days sample.

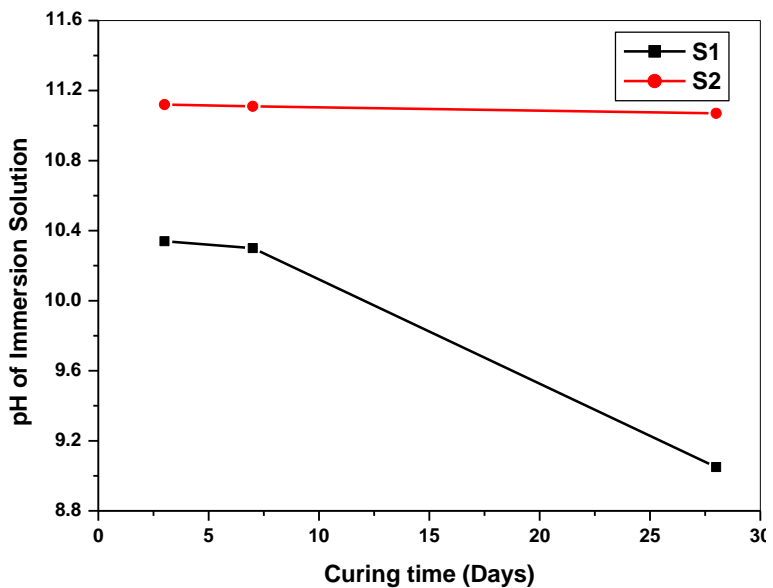

Fig. 5: pH Values of immersion liquid of the two synthesized materials (S1 and S2).

\section{Calcium ion concentration}

The concentration of calcium ion in the immersion liquid for the two synthesized samples is given in Fig. 6. The data indicate that the $\mathrm{Ca}^{++}$ion concentrations for sample $\mathrm{S} 2$ are higher than those of $\mathrm{S} 1$ except a very little increase in $\mathrm{Ca}^{++}$ions for $\mathrm{S} 1$ sample after 7 days curing age. The presence of $\mathrm{Ca}^{++}$ions in the hydration medium of $\mathrm{C}_{3} \mathrm{~S}$ phase is mainly due to the liberation of $\mathrm{Ca}(\mathrm{OH})_{2}$ during the hydration process as given in eq. 1 . Liberation of $\mathrm{Ca}(\mathrm{OH})_{2}$ increases the $\mathrm{pH}$ of the immersion liquid as given in Fig. 5.

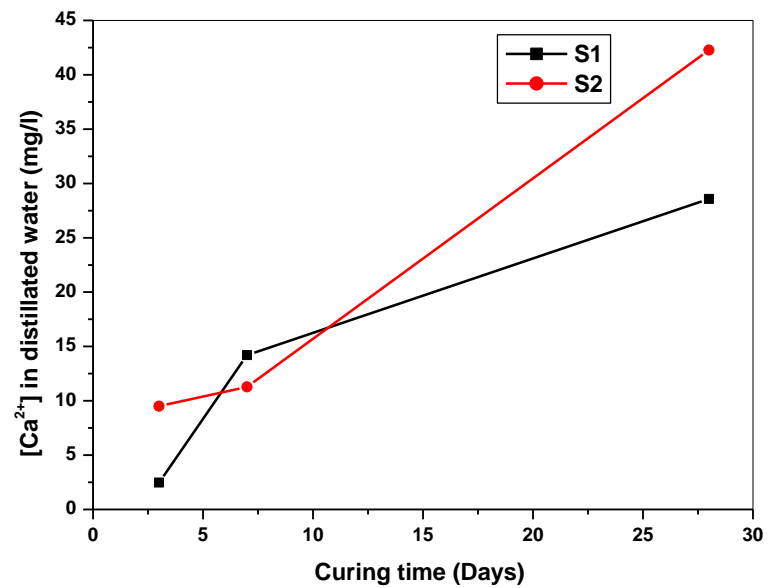

Fig. 6: Calcium ion concentration of the curing liquid of pastes of $\mathrm{S} 1$ and $\mathrm{S} 2$.

\section{X-Ray Diffraction}

Figs. $7 \& 8$ represent the XRD data of the two $\mathrm{C}_{3} \mathrm{~S}$ samples (S1 and S2) cured for 1, 3, 7 and 28 days. Investigation of XRD patterns given in Figs. $7 \& 8$, indicates that by increasing curing periods, there is a diminishing trend in peak height of all characteristics peaks of the anhydrous phases. The XRD data of $\mathrm{C}_{3} \mathrm{~S}$ phase prepared by sol-gel method $\mathrm{S} 2$ (Fig.8) reveals a little more peak diminishing than $\mathrm{S} 1$ prepared by solid state reaction. Overlapping of the characteristic peak of CSH over those of the anhydrous phase could be detected in the two figures. The main XRD peak height of $\mathrm{Ca}(\mathrm{OH})_{2}$ at $2 \theta=18$ is much more clear in XRD pattern of $\mathrm{S} 2$ than $\mathrm{S} 1$ and its intensity increase with curing period in $\mathrm{S} 2$ more than $\mathrm{S} 1$.

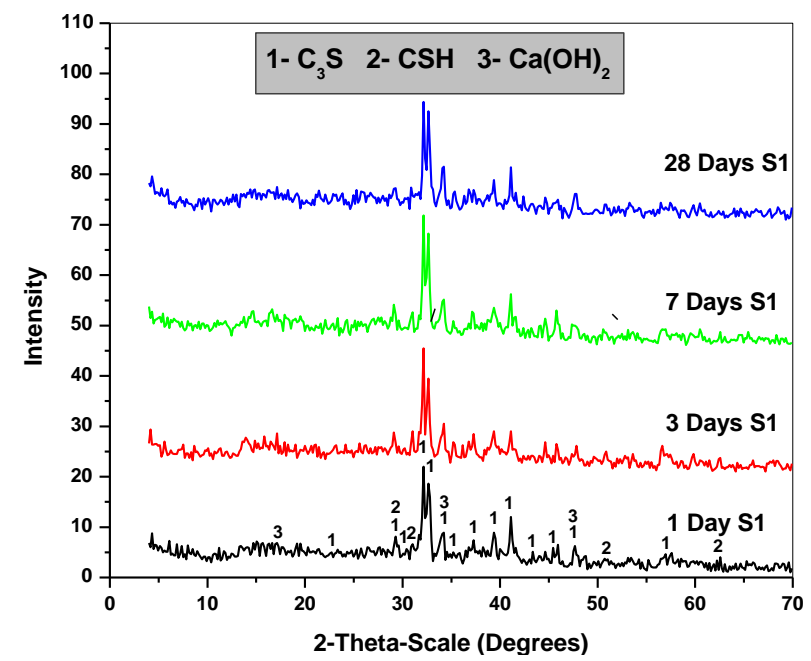

Fig. 7: XRD patterns of pastes of the investigated material S1 cured for 1, 3, 7 and 28 days 


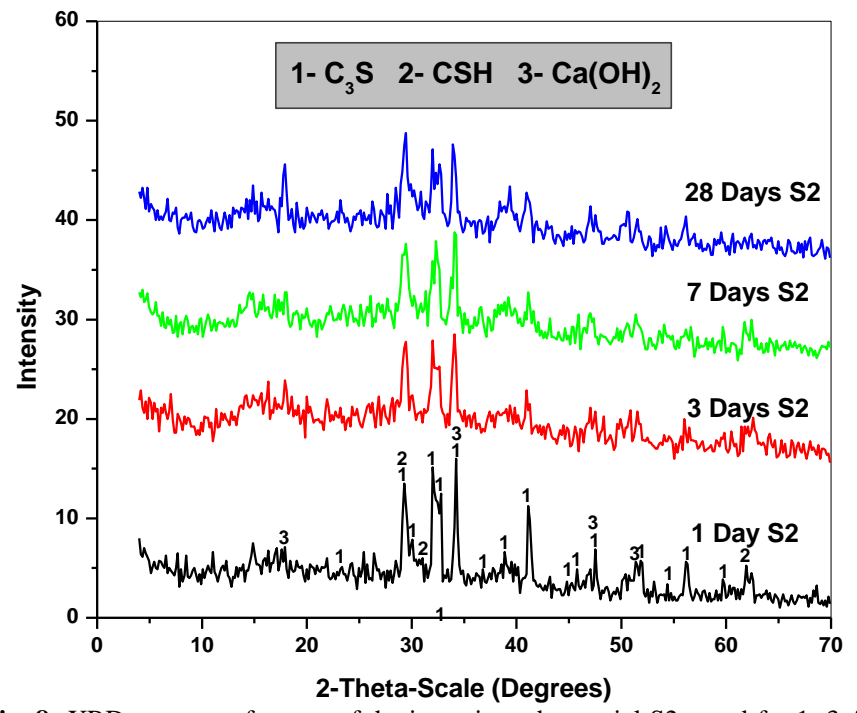

Fig. 8: XRD patterns of pastes of the investigated material $\mathrm{S} 2$ cured for $1,3,7$ and 28 days

\section{FT-IR Spectra}

The infrared spectra of pastes of S1 and S2 samples cured for 1, 3, 7 and 28 days are given in Figs. 9\&10. The IR spectra of calcium silicate phase S1 (Fig. 9), indicates an increasing trend in almost all band intensities of the remaining anhydrous phase at $\approx 500\left(\mathrm{~cm}^{-1}\right)$ and $\mathrm{Si}-\mathrm{O}$ stretching vibration with hydration period because of overlapping of the IR bands of the hydrated compounds at:- 445,815,950 $\mathrm{cm}^{-1}$, and incorporated $v_{2} \mathrm{H}_{2} \mathrm{O}$ and $\mathrm{OH}^{-}$at $1630 \& 3365 \mathrm{~cm}^{-1}$ and $2500 \& 3700 \mathrm{~cm}^{-1}$, respectively, characteristic to the main hydration product $\mathrm{C}-\mathrm{S}-\mathrm{H}$ compound of $\mathrm{C}_{3} \mathrm{~S}$ cement.

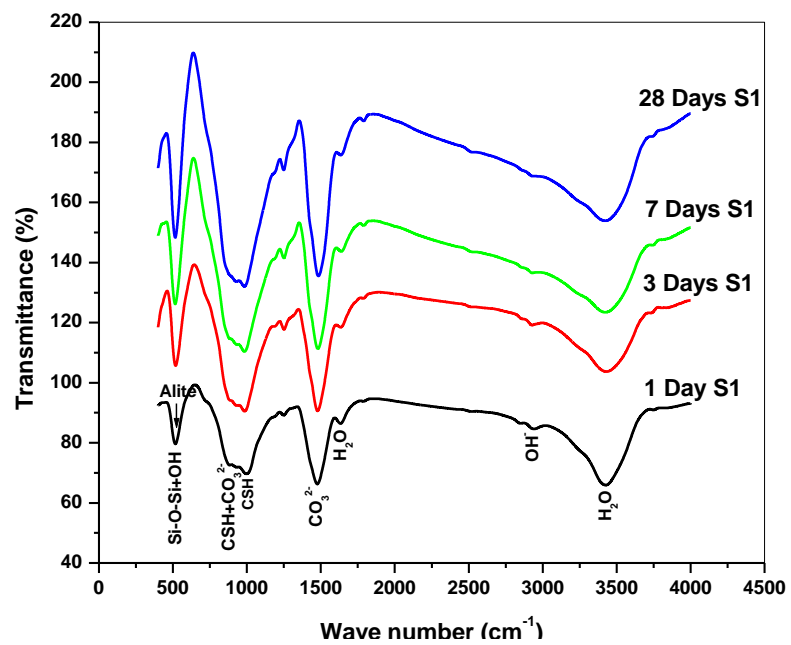

Fig. 9: IR spectra of pastes of the investigated material S1 cured for 1, 3, 7 and 28 days

The main IR bands of Aragonite $\left(v_{2}, \hat{v}_{3} \mathrm{CO}_{3}{ }^{2-}\right.$ antisymmetric stretching) at 850,1490 and $1460 \mathrm{~cm}^{-1}$ is mainly due to the partial carbonation reaction of the hydrated phases by the action of atmospheric carbon dioxide (Gadsden, 1975). Fig. 10 which represents the IR spectra of S2 samples indicates a decrease of the above mentioned bands from 1 to 3 days of curing and then increase again up to 28 days.

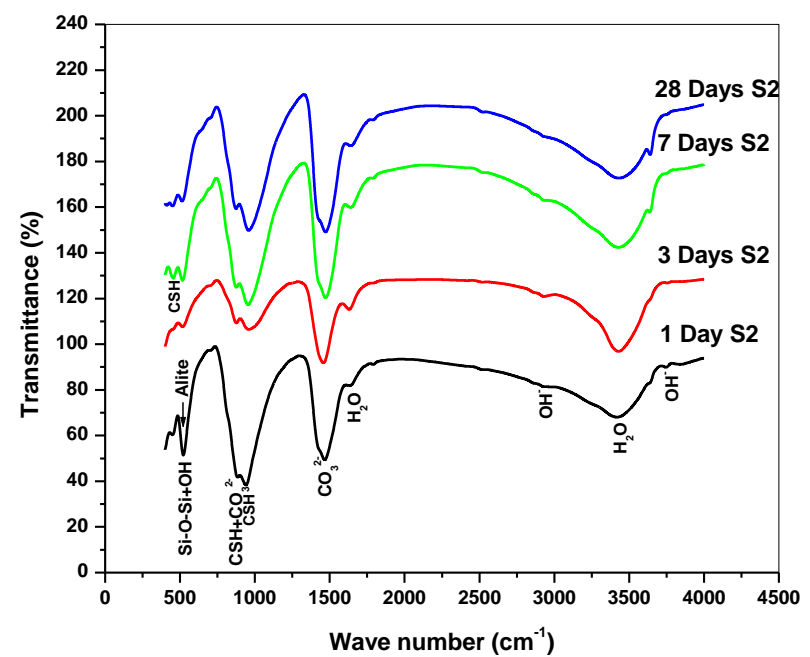

Fig. 10: IR spectra of pastes of the investigated material $\mathrm{S} 2$ cured for 1, 3, 7 and 28 days
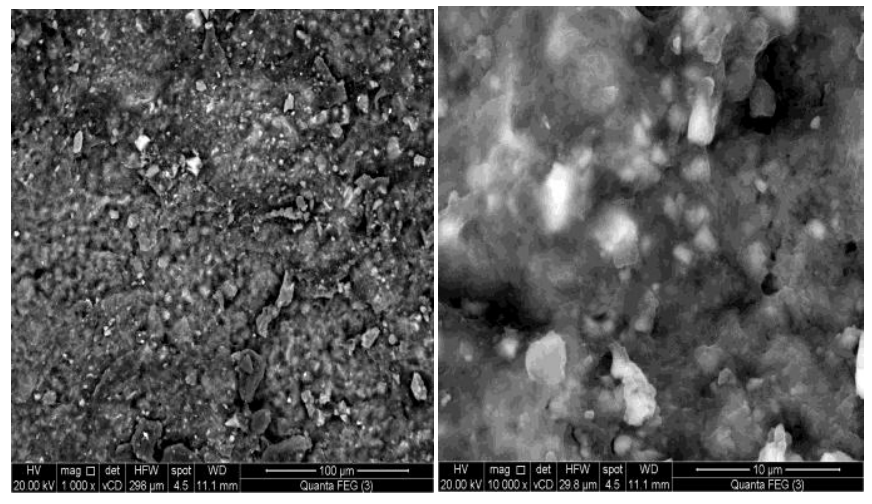

A

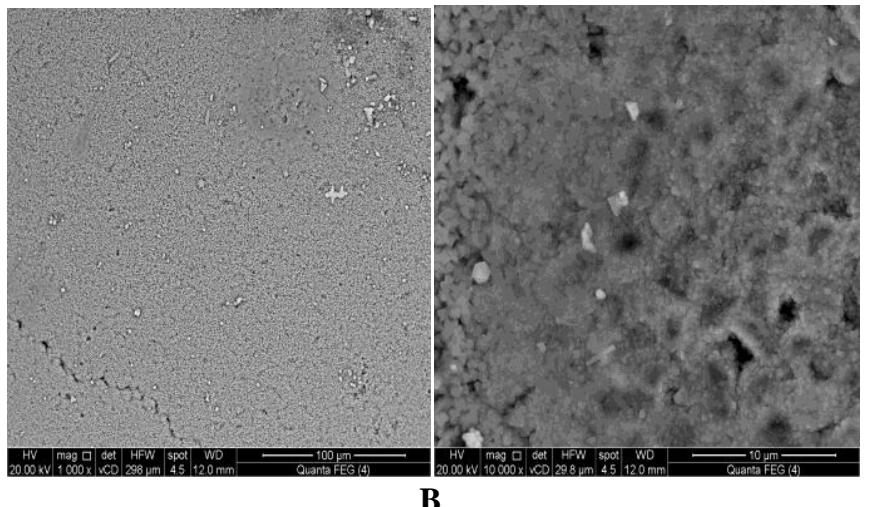

Fig. 11: SEM micrographs of pastes of the two formulated $\mathrm{C}_{3} \mathrm{~S}$ materials cured at 28 days, (a) S1 sample and (b) S2 sample

\section{Scanning Electron Microscopy (SEM)}

Fig. 11 represents the SEM micrographs of 28 days cured pastes of S1 (plates a) and S2 (plates b). Investigation of the micrographs given in Fig. (11) reveals that there is a clear difference in the morphology between the prepared sample S1 and S2.The S2 micrograph (Fig. 11. b) showed more dense structure, the anhydrous $\mathrm{C}_{3} \mathrm{~S}$ grains were found to be covered by a huge gel 
(fibrous) crystals of calcium silicate hydrate $(\mathrm{C}-\mathrm{S}-\mathrm{H})$. The less dense structure of $\mathrm{S} 1$ sample can be seen in the micrographs plate $\mathrm{a}$, in which the coarse anhydrous particles are also embedded in the fibrous crystals of calcium silicate hydrate in more porous system. $\mathrm{Ca}(\mathrm{OH})_{2}$ plates are partially found in a small amounts in the two micrographs.

\section{Antibacterial Test}

Data recorded in Fig. 12 revealed that the release of $\mathrm{Ca}$ ions from test sample S2 showed a better antibacterial activity compared to that of sample S1. Gentamycin effect as an antibacterial agent showed a superior effect than that of releasing $\mathrm{Ca}$ ions from test materials. The clear zone induced post treatment with $\mathrm{S} 1$ showed a clear zone in the order of $3.12 \mathrm{~mm}(26.15 \%)$, while the Gentamycin as a positive control recorded a clear zone of $6.5 \mathrm{~mm}$, while S2 showed a more potential; as antibacterial recording $4.80 \mathrm{~mm}(52 \%)$ as shown in Table 1.

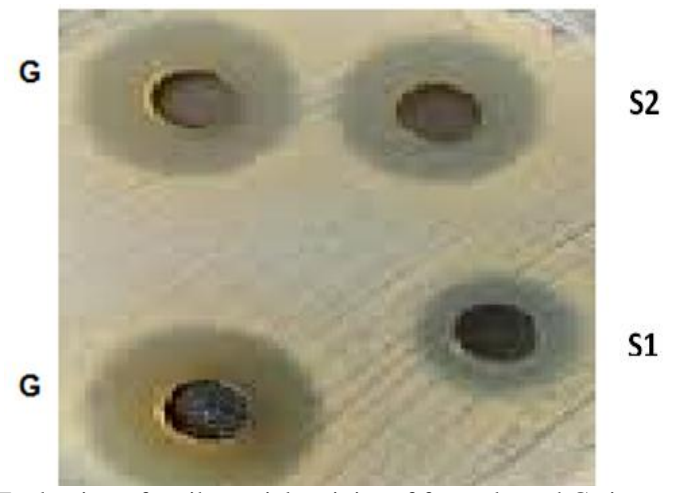

Fig. 12: Evaluation of antibacterial activity of free released Ca ion against Staph aureaus strain using gel diffusion assay Gentamycin $[\mathrm{G}]$ as positive control.

Table 1: Antibacterial activity data for the two formulated $\mathrm{C}_{3} \mathrm{~S}$ phases, $\mathrm{S} 1$ and S2.

\begin{tabular}{cccc}
\hline Sample & CZA mm & RA. mm & \% inhibition \\
\hline Gentamycin Control & 6.50 & --- & --- \\
S1 & 3.12 & 1.7 & 26.15 \\
S2 & 4.80 & 3.38 & 52 \\
\hline
\end{tabular}

Where: CZA: clear zone.

RA: Reduced area.

\section{DISCUSSION}

In general, preparation of high temperature phases in the laboratory is done by firing the appropriate molar ratios of the reactant oxides to temperature at which the phase equilibrium gives the most stable composition. Due to the low temperature stability limit of $\mathrm{C}_{3} \mathrm{~S}$, a rapid cooling rate should be applied to a temperature at which the most kinetically stable phase is maintained. Also, the cooling rate may affect the crystal size of the prepared phase, i.e. the rapid cooling results in a smaller crystal size that is ground more easily. The chemical reactivity of the synthesized phase may be changed if the cooling rate is very slow as the $\mathrm{C}_{3} \mathrm{~S}$ phase may decompose in the temperature range between $1250{ }^{\circ} \mathrm{C}-1100{ }^{\circ} \mathrm{C}$ (Lea, 2004). In this study, the tricalcium silicate phase $\left(\mathrm{C}_{3} \mathrm{~S}\right)$ was prepared by sol-gel method to compare its chemical reactivity during hydration process and the antibacterial activity with that prepared by solid state reaction. The sol-gel method is a wet-chemical preparation reaction between highly pure starting reactants resulting in a well formed final $\mathrm{C}_{3} \mathrm{~S}$ product in the reaction medium before firing process (Zhen et al., 2010). By this way the phase decomposition is prevented and the final product has much more fine nano-size grains (Fig. 2b). The $\mathrm{C}_{3} \mathrm{~S}$ phase (S2) formulated by sol-gel method showed shorter setting time as given in Fig. 3. which is may be attributed to large specific surface area of S2 sample. The presence of large amounts of nano-size grains in the hydration medium may act as nucleating centers that enhances the hydration reaction (Lea, 2004). As was mentioned above, the hydration reaction of $\mathrm{C}_{3} \mathrm{~S}$ phase results in formation C-S-H as a hydration compound and $\mathrm{Ca}(\mathrm{OH})_{2}$ (free lime) as by-product, Eq. 1. this is responsible for high $\mathrm{pH}$ values (alkalinity) of the hydration medium (Taylor, 1997). The $\mathrm{pH}$ data given in Fig. 5, the sol-gel sample (S2) showed higher pH values than $\mathrm{S} 1$ sample prepared by solid state reaction as it may have a relatively more chemical reactivity toward hydration reaction (Camilleri, 2011). The concentration of $\mathrm{Ca}^{++}$ions given in Fig. 6 emphasizes the higher alkalinity of the hydration medium of pastes of sample S2 than S1. The hardness Vickers values represented in Fig. 4.of S2 samples are higher at all curing ages than S1 that is also attributed to the higher hydration reaction rate and more fine grains of S2 sample as mentioned above. By comparing the XRD patterns of pastes of $\mathrm{S} 1$ and $\mathrm{S} 2$ at different hydration periods, Fig. $7 \& 8$, it can be seen that the characteristic peaks of the anhydrous S2 particles are diminishing more clear than those of $\mathrm{S} 1$ with the curing age and the XRD peak of $\mathrm{Ca}(\mathrm{OH})_{2}$ at $2 \theta=18^{\circ}$ could be detected clearly and it increases with curing periods for S2 more than S1 that may be related to better chemical reactivity and enhanced hydration rate of S2 sample. Investigation of the IR spectra of the prepared samples (Figs. $9 \& 10$ ) can explain the aforementioned findings.

The IR spectra of S1 sample, Fig. 9, showed a slight increase of the characteristics band of C-S-H compound, $\left(445,815,950 \mathrm{~cm}^{-1}\right.$, and incorporated $v_{2} \mathrm{H}_{2} \mathrm{O}$ and $\mathrm{OH}^{-}$at $1630 \& 3365$ $\mathrm{cm}^{-1}$ and $2500 \& 3700 \mathrm{~cm}^{-1}$, respectively), while in case of S2 sample these bands showed a little decrease in their intensity due to the fast hydration rate of this sample at the first curing day which results in formation of increasing amounts of hydrated products that may encapsulate the anhydrous particle preventing their further hydration. At later hydration ages (7 and 28 days), this covering layer will be distorted and the water molecules will come in contact with the anhydrous $\mathrm{C}_{3} \mathrm{~S}$ grains (Camilleri, 2008). A continuous increase in the Aragonite bands $\left(v_{2}, v_{3} \mathrm{CO}_{3}{ }^{2-}\right.$ antisymmetric stretching) at 850,1490 and $1460 \mathrm{~cm}^{-1}$ as a result of carbonation process by the action of atmospheric carbon dioxide (Gadsden, 1975).

Data recorded that realize $\mathrm{Ca}$ ions showed an antibacterial potentials, where growth of staph aureuscompare with Gentamycinas a positive control. Data recorded by BystroÈm et al. (1985) demonstrated that the liberated $\mathrm{Ca}(\mathrm{OH})_{2}$ will get rid of all microorganisms if the therapy lasted for one month. Reit and DaÂhlen (1988) found that infection persisted in $26 \%$ of the canals 
after 2 weeks of dressing with calcium hydroxide. SjoÈgren et al. (SjoÈgren et al., 1991) stated that the elimination of the bacteria in root canal could medicate with calcium hydroxide during 7 days in $100 \%$ of the cases. Also, we can conclude that bacterial strain may vary in its reaction to $\mathrm{Ca}^{2+}$ ions and that is time dependent as was stated by Ørstavik and Haapasalo (1990). They found that the use of $\mathrm{Ca}(\mathrm{OH})_{2}$ for 10 days may disinfect the facultative bacteria in dentinal tubules.

Also, direct contact of our extract to test bacterial bay be the cause of antibacterial potentials as released $\mathrm{Ca}$ ions from the formulated $\mathrm{Ca}$ source may depend on the bioactivity, low water solubility and diffusibility. At the same time our data may be on the contrary, to those reported the insistence of the root canal bacteria as reported by Ørstavik et al. (1991), they observed that after one week, the stability of bacteria is about one third of the root canal and Barbosa et al. (1997) stated that after 7 days, a positive cultures may be yielded in some cases, if about $25 \%$ dressed with calcium hydroxide yielded positive cultures. Even cases that yield negative cultures may result in failure (SjoĔgren, 1996; SjoĔgren et al., 1997).

Also, our data may be on the contrary of the other as they explained the bacterial behavior against $\mathrm{Ca}$ ions could be due to the bacterial type tested and $\mathrm{pH}$ value that may cause severe pressure by which some microorganisms will be able to proliferate with the aid of special adaptation mechanisms. Some especial enzymatic and buffering systems may influence the tolerance of the bacteria to $\mathrm{pH}$ variations and help to maintain a constant $\mathrm{pH}$ medium (Padan et al., 1981).

Also, several studies have tested the passivity of free lime in eliminating bacterial cells inside dentinal tubules, where Haapasalo and Ørstavik (1987) stated that a calcium hydroxide paste could not eliminate, even ostensibly, Enterococcus faecalis in the tubules. Safavi et al. (1990) demonstrated that after a long treatment period some bacterial system in dentinal tubules with calcium hydroxide/saline solution as the upper layer bacteria can cover and in turn protect the remaining bacteria deeply allocated in the dental tubules. The $\mathrm{OH}^{-}$ions must diffuse inside the dentine in order to have a deep effect against the bacteria in the dentinal tubules. At the same time it was found that there is a buffering effect for the dentine due to the proton donors, such as $\mathrm{H}_{2} \mathrm{PO}_{4}$, $\mathrm{H}_{2} \mathrm{CO}_{3}$, and $\mathrm{HCO}_{3}$, in hydroxyapatite layer, that may keep the $\mathrm{pH}$ constant (Wang and Hume, 1988; Nerwich et al., 1993). So, to increase the efficiency of $\mathrm{Ca}$ ions to inhibit bacteria in tubules, it is a must for $\mathrm{OH}^{-}$ions diffusion ability to exceed the dentine buffer ability to a $\mathrm{pH}$ level enough to destroy bacteria. The bacterial cell arrangement in root canal may decrease the antimicrobial effects of free lime (Siqueira et al., 1996; Siqueira and Uzeda, 1996). Bacteria colonizing necrotic tissue in ramifications, is thmuses and irregularities are also, probably, protected from the action of calcium hydroxide due to $\mathrm{pH}$ neutralization. Therefore, a shortterm dressing with $\mathrm{OH}^{-}$ions appear to get rid of mainly bacterial cells in this substance as in the main root canal or in the circum pulpaldentine. These areas are also commonly affected by the chemo mechanical procedures. For any medicament, it is a must to diffuse into the root canal to have a successful action (Ørstavik, 1997). A suspension solution of free lime or sustained release $\mathrm{Ca}^{++}$ and $\mathrm{OH}^{-}$ions have great cytotoxic potential due to high $\mathrm{pH}$ values.

\section{CONCLUSION}

The ultra-pure nano-size tricalcium silicate bio-ceramics can be formulated in the laboratory by two different methods, which are solid state reaction ( $\mathrm{S} 1$ sample) and sol gel method (S2 sample). The results indicate that the $\mathrm{S} 2 \mathrm{C}_{3} \mathrm{~S}$ sample has shorter setting time and exhibits better hardness values than $\mathrm{S} 1$ sample prepared by the solid state method. It also showed more alkaline hydration medium with higher $\mathrm{pH}$ values, so, the $\mathrm{C}_{3} \mathrm{~S}$ prepared by sol-gel method could be more reactive than that synthesized by solid state reaction directly at elevated temperatures and slow cooling rate. The data of XRD and IR emphasized these findings. The antimicrobial test of $\mathrm{S} 1$ and $\mathrm{S} 2$ showed that the increasing amount of $\mathrm{Ca}^{++}$ions liberated for S2 (52\% inhibition) sample resulting in a better antibacterial activity compared to $\mathrm{S} 1$ sample (26.15\% inhibition). The antimicrobial results clearly indicate the superior effect of free lime liberated during the hydration reaction of tricalcium silicate phase, which might be used as one of the excellent bioactive materials for both dental applications and bioactive repair material for bone tissue.

\section{ACKNOWLEDGMENTS}

The authors would like to acknowledge and thank Dr. Aly Fahmy Mohamed El-Sayed, Head of research and development sector-Holding Company for Production of Vaccines, Sera and Drugs (EGYVAC) for assistance in testing and interpretation of antimicrobial data.

\section{Financial support and sponsorship: Nil.}

Conflict of Interests: There are no conflicts of interest.

\section{REFERENCES}

Barbosa CAM, GoncËalves RB, Siqueira JF Jr, Uzeda M. Evaluation of the antibacterial activities of calcium hydroxide, chlorhexidine and camphorated paramonochlorophenol as intra canal medicament. A clinical and laboratory study. Endod J. 1997; 23:297-300.

Belío-Reyes IA, Bucio L, Cruz-Chavez E. Phase composition of pro root mineral trioxide aggregate by X-ray powder diffraction. J Endod. 2009; 35:875-878.

BystroÈm A, Sundqvist G. The antibacterial action of sodium hypochlorite and EDTA in 60 cases of endodontic therapy. Endod J. 1985; 18:35-40.

Camilleri J. Characterization and hydration kinetics of tricalcium silicate cement for use as a dental biomaterial. Dent Mater. 2011; 27:836-844.

Camilleri J. Characterization of hydration products of mineral trioxide aggregate. Int Endod J. 2008; 41: 408- 417.

Chen CC, Ho CC, David Chen CH, Ding SJ. Physiochemical properties of calcium silicate cements for endodontic treatment. J Endod. 2009; 35:1288-1291.

Coleman NJ, Awosanya K, Nicholson JW; A preliminary investigation of the in vitro bioactivity of white portland cement. Cem Concr Res. 2007; 37:1518-1523. 
Darvell BW, Wu RC. "MTA"-an Hydraulic Silicate Cement: review update and setting reaction. Dent Mater. 2011; 27:407-422.

Eid AA, Komabayashi T, Watanabe E, Shiraishi T, Watanabe I. Characterization of the mineral trioxide aggregate-resin modified glass ionomer cement interface in different setting conditions. Endod J. 2012; 38:1126-1129. DOI:10.1016/j.joen.2012.04.013.

Estrela C, Sydney GB, Bammann LL, Felippe Júior O. Mechanism of action of calcium and hydroxyl ions of calcium hydroxide on tissue and bacteria. Braz Dent J. 1995; 6:85-90.

Formosa LM, Mallia B, Bull T, Camilleri J. The microstructure and surface morphology of radiopaque tricalcium silicate cement exposed to different curing conditions. Dent Mater. 2012; 28:584-595.

Gadsden JA. Infrared spectroscopy of mineral and related inorganic compounds, Butter Worths. 1975; 16-26.

Gandolfi MG, Ciapetti G, Taddei P, Perut F, Tinti A, Cardoso MV. Apatite formation on bioactive calcium-silicate cements for dentistry affects surface topography and human marrow stromal cells proliferation. Dent Mater. 2010; 26:974-992.

Haapasalo M, Ørstavik D. In vitro infection and disinfection of dentinal tubules. J Dent Res. 1987; 66:137-59.

Lea FM. The chemistry of cement and concrete, 4th. Edn., Peter C. Hewlett. Paperback edition. London; 2004.

McFarland J. An Instrument for estimating the number of bacteria in suspensions used for calculating the opsonic Index and for vaccines. J Am Med Assoc. 1907; 49:1176-1178.

Nerwich A, Figdor D, Messer HH. pH Changes in root dentine over a 4-week period following root canal dressing with calcium hydroxide. Endod J. 1993; 19:302-306.

Nurit J, Margerit J, Terol A, Boudeville P. pH -Metric study of the setting reaction of mono phosphate monohydrate/calcium oxide-based cements. J Mater Sci Mater Med. 1993; 13:1007-1014.

Ørstavik D, Haapasalo M. Disinfection by endodontic irrgants and dressings of experimentally infected dentinal tubules. Endodo and Dent Traumatology.1990; 6:142-149.

Ørstavik D, Kerekes K, Molven O. Effects of extensive apical reaming and calcium hydroxide dressing on bacterial infection during treatment of apical periodontitis: a pilot study. Endod J. 1991; 24:1-7.

Ørstavik D. Intracanal medication. In: Pitt Ford TR, ed. Harty's Endodontics in clinical practice, 4th edn. Oxford, UK: Wright. 1997:106122

Padan E, Zilberstein D, Schuldiner S. pH homeostasis in bacteria. Biochim. et Biophys. Acta. 1981; 650:151-166.

Radwan MM, Abd El-Hamid HK, Nagi SM. Synthesis, properties and hydration characteristics of novel nano-size mineral trioxide and tetra calcium phosphate for dental applications. Orient J Chem. 2016; 32: $2459-2472$

Reit C, DaÂhlen G. Decision making analysis of endodontic treatment strategies in teeth with apical. Endod J. 1988; 21:291-299.

Reyes-Carmona JF, Felippe MS, Felippe WT. Biomineralization ability and interaction of mineral trioxide aggregate and white portland cement with dentin in a phosphate-containing fluid. J Endod. 2009; 35:731-736.
Safavi KE, Spangberg LSW, Langeland K. Root canal dentinal tubule disinfection. J Endod. 1990; 16:207-210.

Sarkar NK, Caicedo R, Ritwik P, Moiseyeva R, Kawashima I. Physicochemical basis of the biologic properties of mineral trioxide aggregate. J Endod. 2005; 31:97-100.

Siqueira JF Jr, Lopes HP, Uzeda M. Atividadeanti bacteriana de medicamentosendodo Ãnticossobrebacte Âriasanaero Âbiasestritas. Revista da APCD. 1996a; 50:326-332.

Siqueira JF Jr, Uzeda M. Disinfection by calcium hydroxide pastes of dentinal tubules infected with two obligate and one facultative anaerobic bacteria. Endod J. 1996; 22:674-676.

Siqueira JR, Lopes HP. Mechanisms of antimicrobial activity of calcium hydroxide: a critical review. J Endod. 1999; 32:361-369.

SjoĖgren U, Figdor D, Persson S, Sundqvist G. Influence of infection at the time of root filling on the outcome of endodontic treatment of teeth with apical periodontitis. Endod J. 1997; 30:297-306.

SjoËgren U, Figdor D, Spangberg L, Sundqvist G. The antimicrobial effect of calcium hydroxide as a short-term intra canal dressing. Endod J. 1991; 24:119-125.

SjoÈgren U. Success and failure in endodontics (Odontological dissertation No. 60). Umea, Sweden: Umea University;1996.

Taylor HFW. Cement Chemistry. Thomas Telford. London;

1997.

Wang JD, Hume WR. Diffusion of hydrogen ion and hydroxyl ion from various sources though dentine. Endod J. 1988; 21:17-26.

Wang X, Sun H, Chang J. Characterization of $\mathrm{Ca}_{3} \mathrm{SiO}_{5} / \mathrm{CaCl}_{2}$ composite cement for dental application. Dent Mater. 2008; 24:74-82.

Wenjuan L, Dong Z, Zhiguang H, Chengtie W, Jiang C. Novel tricalcium silicate/magnesium phosphate composite bone cement having high compressive strength, in vitro bioactivity and cytocompatibility. Acta Biomat. 2015; 21:217-227.

Zhao W, Wang J, Zhai W, Wang Z, Chang J. The self-setting properties and in vitro bioactivity of tricalcium silicate. Biomater. 2005; 26:6113-6121.

Zhao WY, Chang J. Sol-gel synthesis and in vitro bioactivity of tricalcium silicate powders. Mater Lett. 2004; 58:2350-2353.

Zhen $\mathrm{H}$, Wenquan L, Lei W, Jie W. Synthesis of $\mathrm{C}_{3} \mathrm{~S}$ by SolGel technique and its features, Journal of Wuhan University of Technology-Mater. Sci Ed. 2010; 25:138-141. DOI 10.1007/s11595-0101138-0.

\section{How to cite this article:}

El-Hamid HK, Abo-Almaged HH, Radwan MM. Synthesis, characterization and antimicrobial activity of nano-crystalline tricalcium silicate bio-cement. J App Pharm Sci, 2017; 7 (10): 001008. 